\title{
The determinants of strategic innovation-driven competitiveness of mining companies
}

\author{
Yuliia Lazarenko ${ }^{1, *}$, Olga Garafonova $^{1}$, Vyktoriia Marhasova ${ }^{2}$, and Svetlana Grigashkina ${ }^{3}$ \\ ${ }^{1}$ Kyiv National Economic University named after Vadym Hetman, Management Department, 03057, \\ 54/1 Pr. Peremogy, Kyiv, Ukraine \\ ${ }^{2}$ Chernihiv Polytechnic National University, Department of Theoretical and Applied Economics, \\ 14035, Chernihiv, Shevchenko str.,95, Ukraine \\ 3 T. F. Gorbachev Kuzbass State Technical University, 650000, 28 Vesennyaya St., Kemerovo, \\ Russia
}

\begin{abstract}
The paper is intended to examine the main determinants of the strategic innovation-driven competitiveness of a company that operates in the mining sector. Based on the literature review and industry analysis reports, it is shown that mining companies need to develop specific capabilities in order to devise and implement appropriate innovation-driven strategies and achieve sustainable competitive advantage. As a result of the study, using a system approach a descriptive overview of the main factors affecting the strategic innovation-driven competitiveness according to the specific features of the mining industry is presented. From a practical perspective, the paper provides an analytical framework for the identification of the core organizational capabilities and managerial aspects on which attention should be especially focused in order to gain and hold a strategic competitive advantage and enhance the organizational performance of mining enterprises in the modern business environment.
\end{abstract}

\section{Introduction}

The global knowledge-based economy is driven by innovation which is the leading force of competitiveness, growth, and profitability. The rapid changes in the requirements of consumer needs, as well as those in the technological field are drivers for disruptive and incremental innovations, which can be considered as new or improved products, processes, technologies, organizational and managerial decisions (or a combination thereof), that have been introduced on the market or brought into use by the company.

The paper aims to systematize the key elements and factors that influence the strategic innovation-driven competitiveness of enterprises in the mining sector. The main purpose of the paper is to present a descriptive overview of the determinants of strategic competitive advantages given the peculiarities of innovation-active companies which operate in the mining industry. According to international statistical guidelines and recommendations, an innovation-active firm can be defined as a company that is engaged in one or more

* Corresponding author: yuliia.lazarenko@,kneu.ua 
activities to develop or implement new or improved products or business processes for an intended use. Based on a literature review, the definition of the strategic innovation-driven competitiveness of a company as an economic category is proposed, as well as the main dimensions and prerequisites for effective management of innovation-active enterprises' competitiveness in the mining industry are highlighted, that should be primarily taken into account from a management decision-making viewpoint to improve the organizational performance as well as create and maintain competitive advantages in a fast-changing business environment.

\section{Materials and Methods}

In modern society, based on knowledge and innovative technologies, there is a tendency towards the intensification of market competition between business organizations, which raises the importance of developing and implementing effective management mechanisms in order to ensure the strategic competitive advantages of enterprises. Mining companies strive to achieve a higher level of competitiveness because a strong competitive position on the market gives the opportunity to enhance organizational performance, increase operational efficiency, and maintain the vitality of the company. These conditions require the company to develop an appropriate management system of strategic competitiveness, which is based on innovations. In this context, the study aims to provide a theoretical framework and develop managerial recommendations for ensuring the level of strategic innovation-driven competitiveness in the mining industry.

The paper is structured as follows: first, the relationship between innovation activities, organizational capabilities, and the strategic competitiveness of a company is explained. Then, based on literature review and existing industry analysis reports an analytical framework for exploring the core organizational capabilities on which attention should be focused in order to gain and hold the competitive advantage and enhance the organizational performance of mining enterprises is presented. As a result of the study, through a system approach a descriptive overview of the company's strategic innovation-driven competitiveness determinants is provided, with a particular emphasis on the specific organizational capabilities that enable mining companies to adapt to changing environments and achieve sustainable competitive advantage.

\section{Results and Discussion}

Nowadays identification of main determinants of strategic competitive advantage of innovation-active mining companies has become critical for the development of managerial measures, mechanisms, and appropriate instruments for increasing the level of their competitiveness. The innovation activity of an enterprise is one of the most widespread categories, which are used in research related to the issues of innovation development. Following the international statistical approach, innovation activities of the enterprise can be defined as all scientific, technological, organizational, financial, and commercial steps which actually, or are intended to, lead to the implementation of innovations [1]. This category includes a set of goal-directed activities, which aim at the development, implementation, and market promotion of new or improved products, services, technologies, as well as organizational and managerial solutions or as an organization's characteristic which reflects its ability to innovate. In this paper to determine the category of innovation-active enterprise, we consider it appropriate to use the international recommendations on innovation statistics, according to which an innovation-active firm is one that has had innovation activities during the period under review, including those with 
ongoing and abandoned activities. In other words, firms that have had innovation activities during the period under review, regardless of whether the activity resulted in the implementation of an innovation, are innovation-active [2].

During the past years, many studies have been conducted which are related to the relationship between innovation activities and the strategic competitiveness of business entities. Empirical findings have revealed that such determinants as knowledge, new technologies, and innovation capacity have become crucial components of strategic competitiveness and one of the basic conditions for modern companies to sustain their vitality within the global economy [3; 4]. However, although it is an important issue for enterprises to analyze the determinants of strategic competitive advantage, some aspects of managing the competitiveness of innovation-active mining companies, particularly in terms of the creation and maintaining of strong competitive advantage are still not sufficiently researched and require further study.

Profound changes which have taken place in the economy in the last two decades have led to its radical transformation towards innovation and sustainable development, that should be taken into account to ensure the strategic competitiveness of mining operators in the modern competitive struggle, both in Europe and worldwide [5; 6]. In this context, the mining companies are forced to manage resources more efficiently, to increase their flexibility in order to adapt to supply and demand imbalances and changes in the economic and technical environment, as well as to ensure the strategic competitive advantages in the markets on which they operate taking into consideration such factors as decreasing ore grades, deeper deposits, combined with an increasing environmental and social awareness and active introduction of low-waste technologies.

From a theoretical perspective, strategic competitiveness can be defined as an organization's ability to face competition that results from the successful development and implementation of a superior value-creating strategy. When a company implements such a strategy and other companies in the market are unable to duplicate it this firm becomes a sustainable competitive advantage [7]. In order to identify the sources of strategic competitive advantage of the mining enterprises, it is necessary to consider a holistic approach that includes such concepts as resource management, operational performance improvement, and a mining value chain that combines resource-related activities and industrial activities $[5 ; 8]$. For a long time it has been considered that in the mining sector the generation of value is based primarily on industrial-type activities which are focused on the manufacturing costs reduction and provide on this basis the creation of competitive advantage. In view of the changes in economic and technological environments, it was assumed that the main determinants that influence value generation in mining companies are concentrated in the activities, focused on proper management and operational performance improvement. Thus, a necessary condition to achieve strategic competitiveness involves the development of activities related to the company's performance improvement with regard to an increased awareness of the role of innovation and sustainability in the mining sector.

The innovation-driven competitiveness can be considered as an integrative dynamic characteristic of a company which assumes that the accumulated knowledge, skills, and technological competencies are the key determinants of a firm's innovation performance and a primary source of its competitive advantages. The survival capacity as well as the ability to ensure sustainability and financial performance can be identified as key characteristics of the strategic competitiveness of mining operators. In this regard, innovation is also closely associated with the firms' potential to succeed in the market and to adapt to environmental changes [9]. Innovation is considered not only as a critical factor in the improvement of operational performance in the mining industry through increasing the efficiency of its processes and reducing manufacturing costs but also as a tool to meet 
the increasing social and environmental concerns among communities and authorities by providing suitable solutions to surpass industrial difficulties and ensure the continuity and sustainability of the mining activity [10].

However, there remain significant challenges and barriers to innovation in the mining sector which need to be addressed, such as a short-term focus on exploration, the difficulties of gaining access to the right type of knowledge and technologies, a restrictive type of mindset that causes a conservative attitude towards innovation, as well as a lack of employees with the right type of skills and competencies which required for development and effective implementation of innovation-driven strategies.

Following the principles of the system approach, the analytical framework of the study includes three key aspects: business context, organizational context, and potential competitive advantage of the company (Fig. 1). The business context includes the actors (organizations, industrial structures, governments, local communities etc.) who play a significant role in the business environment and can influence a company's competitive position within the respective industry.

The organizational context includes a set of capabilities that can be defined as the main determinants of the strategic innovation-driven competitiveness of a company, namely innovation capability, organizational and managerial capability, and cooperation and network capability. The competitive advantages are considered as the outcomes which result from strategic assets and capabilities and are grouped into three categories: financial dimension (value creation and reduction of the costs), and non-financial assets in terms of reputation among customers, stakeholder satisfaction and sustainability.

With regard to the non-financial dimension of competitive advantage, empirical findings have indicated that stakeholder satisfaction is relevant for the competitive position of the company and organizational sustainable success [11]. It should be noted that in the context of the mining industry a company's relationships with critical stakeholders, mainly shareholders, suppliers and partners, employees, customers, and local communities may lead to better performance, as organizations while integrating business and social considerations, meet the needs and expectations of the interested parties in a balanced way and create value for their stakeholders.

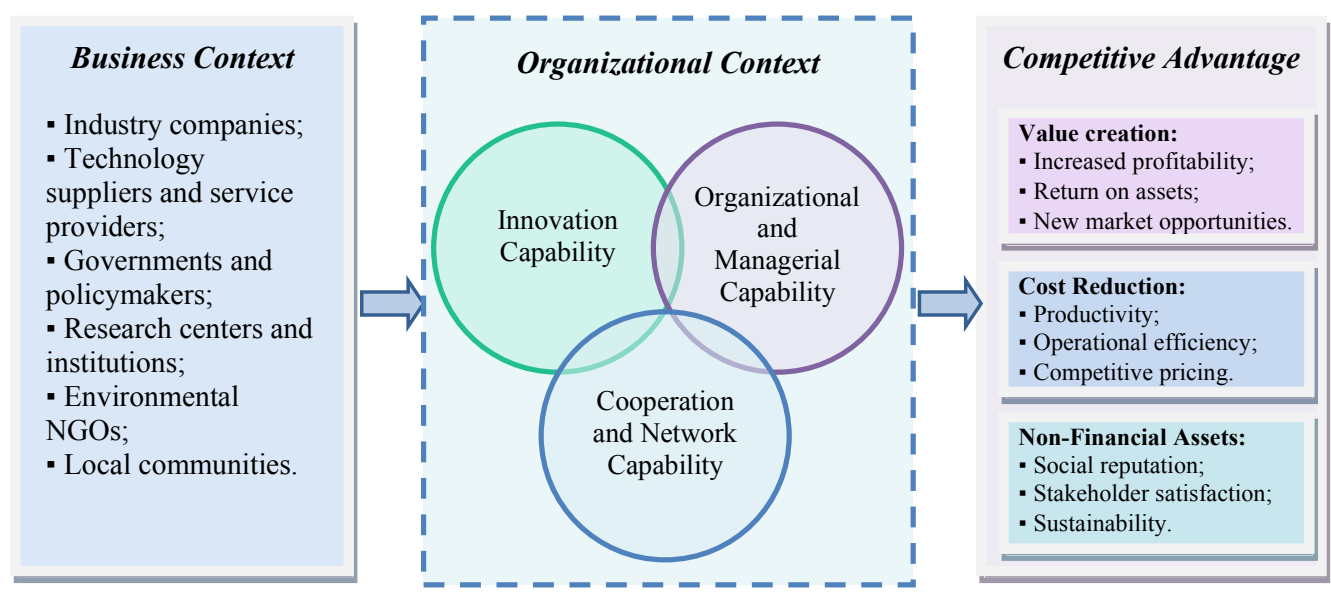

Fig. 1. An analytical framework for exploring strategic innovation-driven competitiveness in the mining sector

Source: Developed by authors adapting [3-7; 9-12; 16-17]

In the scientific literature there are different approaches to the definition of the company's strategic competitiveness. According to the resource-based approach, the source 
of competitive advantage and, thereby, the profitability of an organization is the set of firmspecific resources which are under the control of the company to ensure value growth. These strategic assets may be tangible or intangible or may take the form of managerial capabilities $[13 ; 14]$. In this regard, the strategic innovation-based competitiveness of an enterprise can be viewed as a dynamic characteristic, which reflects the level of its innovation capability. This category can also be defined as the company's ability to operate successfully and to be competitive in the market at the expense of implemented innovations.

Summarizing the existing approaches it can be concluded that the strategic innovationbased competitiveness of an organization can be defined as the ability of the enterprise to ensure efficient performance and maintain a competitive position on the market in the long term through the adaptation to the environmental changes by managing competitive advantage through the implementation of different types of innovations and according to the sustainable development principles.

Strategic innovation-based competitiveness of the enterprise is an integrative concept, that is why in order to analyze its economic nature is necessary to take into consideration various aspects and factors of influence. The main determinants of strategic innovationdriven competitiveness of mining companies are shown in Fig. 2.

\section{The Main Determinants of the Strategic Innovation-Driven Competitiveness of Mining Companies}

\begin{tabular}{|c|c|c|}
\hline Innovation capability & $\begin{array}{l}\text { Organizational and } \\
\text { managerial capability }\end{array}$ & $\begin{array}{l}\text { Cooperation and network } \\
\text { capability }\end{array}$ \\
\hline $\begin{array}{l}\text { human, financial, } \\
\text { physical, and } \\
\text { organizational capital } \\
\text { (tangible and } \\
\text { intangible); } \\
\text { employees' knowledge, } \\
\text { skills, core } \\
\text { competencies; } \\
\text { attitude to innovation; } \\
\text { information and } \\
\text { communication } \\
\text { technologies; } \\
\text { technical knowledge, } \\
\text { skills, and education; } \\
\text { internal efforts to } \\
\text { improve the technology. }\end{array}$ & $\begin{array}{l}\text { a value-creating strategy; } \\
\text { functions, mechanisms, } \\
\text { and tools of strategic } \\
\text { management; } \\
\text { strategic flexibility and } \\
\text { capability to change; } \\
\text { entrepreneurial thinking; } \\
\text { an innovative type of } \\
\text { mindset; } \\
\text { an innovation-oriented } \\
\text { organizational structure; } \\
\text { an innovative } \\
\text { organizational } \\
\text { environment; } \\
\text { the efficiency of } \\
\text { communication. }\end{array}$ & $\begin{array}{l}\text { - } \text { the ability to maintain } \\
\text { production and } \\
\text { consumption linkages: } \\
\text { backward linkages: } \\
\text { interaction of the company } \\
\text { with firms which supply to } \\
\text { the sector (transportation } \\
\text { and construction firms; } \\
\text { mining equipment } \\
\text { producers etc.); } \\
\text { forward linkages: } \\
\text { interaction with firms } \\
\text { which use the sector's } \\
\text { goods as inputs (steel } \\
\text { mills; coal power stations } \\
\text { etc.). }\end{array}$ \\
\hline
\end{tabular}

Fig. 2. The determinants of the strategic innovation-driven competitiveness of a mining company

Source: Developed by authors adapting [7-8; 12-17].

The potential sources of competitive advantage of an innovation-active enterprise may include research and development, superior quality or features of innovative products, patents and trademarks, effective competitor and customer intelligence systems, strong organizational goodwill, strategic alliance agreement etc. Among the most important factors of the external environment, which influence the level of strategic innovation-driven 
competitiveness of a company, the following should be mentioned: the macro-environment conditions, an appropriate innovation policy, informational and infrastructural support for promoting innovation-oriented activities, the intensity of rivalry among competitors in the industry, the institutional framework, and others. Due to the nature of the mining sector, the environmental component is one of the significant external factors affecting the choice of the complex use of mineral and raw material resources for extracting new components and manufacturing new products. In the long-term perspective the strategic competitiveness of the company is ensured by the identification of a unique competitive advantage in combination with the optimal strategy of their development.

As shown in Fig. 2, the necessary prerequisite for the strategic competitive advantage of a mining company is the innovation capability, which determines its ability to transform knowledge and ideas into new products, processes, and systems for the benefit of the firm and its stakeholders [18]. In a knowledge-intensive business environment, the innovation capability can also be considered as an integrative concept that is formed by four key capabilities: technology development, operations, management, and transaction [19]. The integration between all the four key elements promotes innovation which creates strategic competitive advantages.

It can be concluded that the strategic competitiveness of the mining sector is affected by the availability of mineral resources and their usage efficiency under the conditions of the mineral and raw material base quality deterioration, as well as a set of various internal and external (social, economic, political, and ecological) factors, and the companies' ability to respond to changes in the external environment. Targeted partnerships, strategic collaborative relationships, and networked interactions also contribute to strengthening network capabilities which in turn promotes the increase of competitiveness. In this regard, it should be mentioned that it is impossible for companies to operate independently and be isolated from the surrounding business environment therefore, the formation of clusters to deliver collaborative solutions for the mining industry is also essential for the competitiveness of the sector.

The current global trends towards the shift from a traditional economy to an environmentally sustainable one, lead to the active introduction of low-waste technologies and the more efficient use of available resources. Therefore, the strategic competitiveness of mining companies is determined not only by the availability of mineral resources but also by effective planning and management on the basis of innovative technological and organizational solutions. Empirical findings have indicated that organizations which operate in the mining sector and use strategic management concepts and appropriate analytical tools are more profitable than those that do not. In accordance with it, there is a positive relationship between strategic management dimensions and business performance [20]. There remain however significant challenges for effectively managing strategic competitive advantages. In this vein, it is recommended for the mining companies to establish formalized strategic management process and use appropriate analytical tools for the continuous analysis of the factors of the external business environment, as well as internal resources, capabilities, and core competencies in order to gain strategic competitive advantage and ensure the company's vitality.

\section{Conclusions}

Nowadays mining operators face tough challenges when it comes to increasing their profitability, developing key skills and competencies, and providing stakeholder satisfaction. The complex nature of the environment within which mining companies 
operate requires strategic thinking, flexibility, and innovation in order to create and maintain competitive advantages.

Based on the findings of the study, it is possible to outline practical aspects of managing the strategic competitiveness of mining companies which operate in today's innovationdriven business environment. In order to ensure competitive advantages mining companies need to focus on the key aspects of their operational strategies which form the basis for long-term strategic planning. It is crucial for the companies to define the clear objectives of innovation activity and to develop the innovation strategy which should be aligned with the company's vision. The initial steps of the company include the process of analyzing the factors of its external and internal environment to determine available resources, capabilities, skills, and core competencies which can be considered as a source of its strategic competitive advantages and use this as the basis for the sustainable business model development. The strategic competitive advantage should be determined for a particular company under given specific industry conditions and organizational objectives. It allows a company to differ from other industry enterprises thus providing an opportunity to hold a lead position in the sector. It should be noted that strategic competitive advantage should not only be achieved and maintained but also revised over time to ensure that they reflect changes in market demands and technologies of production, as well as current trends in the business environment. Against this background, mining companies should be dynamic, being in a continuous process of strategic development and improvement of organizational capabilities. In this case, they will be able not only to increase the level of their own strategic competitiveness but also ensure the competitiveness of the entire mining sector in the long term.

\section{References}

1. OECD. The Measurement of Scientific and Technological Activities: Guidelines for Collecting and Interpreting Innovation Data: Oslo Manual, Third Edition. Prepared by the Working Party of National Experts on Scientific and Technology Indicators (Paris, OECD, 2005)

2. OECD. Oslo Manual 2018: Guidelines for Collecting, Reporting and Using Data on Innovation. 4th Edition. The Measurement of Scientific, Technological and Innovation Activities (OECD, Eurostat, 2018)

3. E. Akis. Procedia - Social and Behavioural Science, 195, 1311 (2015)

4. E. Dogan. Ekonometri ve İstatistik Say1, 24, 60 (2016)

5. D. Csiminga, S. Mangu, M. Iloiu et al., Procedia Economics and Finance, 23, 428 (2015)

6. A. Vorster. The Journal of the South African Institute of Mining and Metallurgy, 3, 61 (2001)

7. Strategic Management: Competitiveness and Globalization: Concepts. Ninth Edition. Michael A. Hitt, R. Duane Ireland, Robert E. Hoskisson (West Publishing Company, 2011)

8. J. Garcia, J. Camus, P. Knight. Creating Competitive Advantage in Mining: An Illustrative Comparation with the Oil Industry, Proceedings of the 4th International Conference on Mining Innovation, MININ 2010. The Fourth International Conference on Mining Innovation (Santiago, Chile, 23-25 June 2010)

9. R. Dobrinsky. Innovation as a Key Driver of Competitiveness. United Nations Economic Commission for Europe (United Nations ECE, Annual Report, 2008)

10. F. Sánchez, P. Hartlieb. Mining, Metallurgy \& Exploration, 37, 1385 (2020) 
11. L. Fonseca, A. Ramos, A. Rosa, A.C. Braga, P. Sampaio. International Journal of Industrial and Systems Engineering, 2:2, 144 (2016)

12. UNDP and UN Environment. Managing mining for sustainable development: $A$ sourcebook (Bangkok, United Nations Development Programme, 2018)

13. J.B. Barney. Journal of Management, 17:99, 120 (1991)

14. S. Morris. Environmental Pollution and Competitive Advantage: An Exploratory Study of US Industrial-Goods Manufacturers. The Academy of Management Conference Proceedings (The Academy of Management, New York, 1997)

15. M. Morris, R. Kaplinsky, D. Kaplan. Resources Policy, 37:4, 408 (2012)

16. F. Hermundsdottir, A. Aspelund. Journal of Cleaner Production, 280:1, 1 (2020)

17. Maria Elena Baltazar Herrera. Journal of business research, 68, 1468 (2015)

18. B. Lawson, D. Samson. International Journal of Innovation Management, 5:3, 377 (2001)

19. P.A. Zawislak, A.C. Alves, J. Tello-Gamarra, D. Barbieux, F.M. Reichert. Journal of Technology Management and Innovation, 7:2, 14 (2012)

20. Dinko Herman Boikanyo, Ronnie Lotriet and Pieter W. Buys. Problems and Perspectives in Management, 14:3, 483 (2016) 